\title{
Correction to: Effect of Soil Improvement Techniques on Increasing the Lateral Resistance of Single Piles in Soft Clay (Numerical Investigation)
}

\author{
Saeid Eltaweila $\mathbb{D} \cdot$ Marawan M. Shahien $\cdot$ Ahmed M. Nasr - Ahmed Farouk
}

Published online: 22 May 2021

(C) Springer Nature Switzerland AG 2021

\section{Correction to:}

\section{Geotech Geol Eng https://doi.org/10.1007/s10706-020- 01534-9}

In the original publication of the article, the fifth author was inadvertently added in the author group.
The correct author group is given in this Correction and the original article has been corrected.

Publisher's Note Springer Nature remains neutral with regard to jurisdictional claims in published maps and institutional affiliations.

The original article can be found online at https:// doi.org/10.1007/s10706-020-01534-9.

S. Eltaweila $(\bowtie)$

Civil Engineering Department, Tanta University,

Wild Asfir, Sedi Salem 33633, Egypt

e-mail: Saeid.eltaweila2015@gmail.com

M. M. Shahien

Civil Engineering Department, Tanta University,

Bajour, Menofia 32821, Egypt

e-mail: Marawan.shahin@f-eng.tanta.edu.eg

A. M. Nasr

Civil Engineering Department, Tanta University,

Sedi Gaber, Alexandria 21519, Egypt

e-mail: ahmed.nasr@f-eng.tanta.edu.eg

\section{A. Farouk}

Civil Engineering Department, Tanta University,

Tanta 31526, Egypt

e-mail: drafarouk@f-eng.tanta.edu.eg 